\title{
PROTOZOAN DISTRIBUTION IN FARMED CYPRINID FISH FROM MACEDONIA
}

\author{
*Dijana BLAZHEKOVIKJ - DIMOVSKA ${ }^{1}$, Stojmir STOJANOVSKI ${ }^{2}$ \\ ${ }^{\text {I} F a c u l t y ~ o f ~ B i o t e c h n i c a l ~ S c i e n c e s, ~ U n i v e r s i t y ~,, ~ S t . ~ K l i m e n t ~ O h r i d s k i ”, ~ B i t o l a, ~ N . ~ M a c e d o n i a ~}$ \\ ${ }^{2}$ Hidrobiological Institute, Ohrid, N. Macedonia \\ dijanablazekovic@yahoo.com \\ *Corresponding author \\ Received $17^{\text {th }}$ November 2020, accepted 30 ${ }^{\text {th }}$ March 2021
}

\begin{abstract}
The main purpose of this research was to analyze protozoan distribution in farmed cyprinid fish from Macedonia which can have a negative economic impact in developing countries where aquaculture activities contribute to food production. The parasitological examinations were performed on the four fish species from the most significant and larger cyprinid aquaculture facilities in Macedonia. A total of 1134 fish samples were examined, from which parasite infestation with Protozoa was determined in 533 fish, with a total prevalence of $47.002 \%$ and a mean intensity of 6.492. Eight representatives of protozoan parasites in farmed cyprinid fish were identified in this study: Apiosoma piscicola, Chilodonella hexasticha, Myxobolus müelleri, Myxobolus encephalicus, Thelohanellus nikolskii, Ichthyophthirius multifiliis, Trichodina sp. (in common carp), and Trichodina sp. (in grass carp). The finding of Chilodonella hexasticha in common carp (Cyprinus carpio) as a first record for Macedonian waters, is first published in this paper.
\end{abstract}

Keywords: cyprinid aquaculture, protozoan parasites, prevalence, mean intensity

\section{Introduction}

According to [1], parasitic protozoan diseases are responsible not only for great losses to the commercial fishing industry, but also for a negative economic impact in developing countries where aquaculture activities contribute to food production to the need of the population.

From [2] and [3] found that ecto and endoparasitic protozoa are some of the most dangerous threats to the fish population. According to the authors, even a moderate infection with these organisms can cause fatal disease, because the infected fish lose their appetite and stop consuming food. [4] reported that most of the protozoa live in commensalism with their hosts, while some species have adapted to parasitic relationships to fish, representing their ectoparasites.

From [5] stated that parasitic protozoa of at least seven different types have been identified in fish, including endo and ectoparasites with a wide range of life cycles and pathology. [6] reported that in many cases, certain protozoa species cause secondary infections with other pathogens, such as viruses, fungi, and bacteria. At the same time, they are one of the most dangerous parasitic groups that are likely to cause more disease in the fish population than any other parasite species.

\section{Materials and methods}

Samples of four fish species including common carp (Cyprinus carpio), grass carp (Ctenopharingodon idella), silver 
carp (Hypophtalmichthys molitrix), and bighead carp (Hypophtalmichthys nobilis) from the most significant and larger cyprinid aquaculture facilities in Macedonia, including fish ponds and cage farms on reservoirs, were examined for parasitological investigations.

This study was carried out by seasons, in a period of three years. The specimens were placed in plastic tanks with fishpond water and immediately transferred to the research laboratory or were inspected on the spot.

During the dissection, gills, fins and skin were examined using stereomicroscopes „Zeiss”- Stemi DV4 and „MBS 10”, as well as microscopes „Zeiss"- PrimoVert and „Reichart”, at the Department for fish diseases in Hydrobiological Institute Ohrid (Macedonia). All parasites found in each fish were identified and enumerated.
During the study period, data on parasite species were categorized according to the season, including prevalence and mean intensity. Classical epidemiological variables (prevalence and mean intensity) were calculated according to [7].

The parasite specimens were identified using reference keys of [8].

\section{Results and discussion}

During the parasitological examinations of the fish from the most significant and larger cyprinid aquaculture facilities in Macedonia, a total of 1134 fish samples were examined, from which parasite infestation with Protozoa was determined in 533 fish, with a total prevalence of $47.002 \%$ and a mean intensity of 6.492 (Table 1).

Total prevalence and mean intensity with representatives of Protozoa in

Table 1. cyprinid aquaculture facilities in Macedonia

\begin{tabular}{c|cccc}
\hline Parasites & $\begin{array}{c}\text { Number of } \\
\text { examined fish }\end{array}$ & $\begin{array}{c}\text { Number of } \\
\text { infected fish }\end{array}$ & Mean intensity & Prevalence \\
\hline Protozoan species & 1134 & 533 & 6.492 & $47.002 \%$ \\
\hline
\end{tabular}

Whereby from the representatives of Protozoa, 8 species were identified: Apiosoma piscicola, Chilodonella hexasticha, Myxobolus müelleri, Myxobolus encephalicus, Thelohanellus nikolskii, Ichthyophthirius multifiliis, Trichodina sp. (in common carp) and Trichodina sp. (in grass carp). Based on the total number of fish examined (1134), the highest prevalence with protozoan parasites is confirmed with Trichodina sp. (in common carp) (30.159\%), followed by Apiosoma piscicola (6.996\%), Ichthyophthirius multifiliis (4.233\%), Thelohanellus nikolskii (3.086\%),
Myxobolus encephalicus $(0.794 \%)$, Trichodina sp. (in grass carp) $(0.794 \%)$, Chilodonella hexasticha $(0.441 \%)$ and Myxobolus müelleri $(0.441 \%)$. The highest mean intensity with protozoan parasites is determined with Ichthyophthirius multifiliis (26.479), followed by Trichodina sp. (in grass carp) (7.556), Trichodina sp. (in common carp) (4.567), Apiosoma piscicola (4.241), Myxobolus encephalicus (4.000), Myxobolus müelleri (3.400), Thelohanellus nikolskii (2.444) and Chilodonella hexasticha (1.800) (Table 2). 
Mean intensity and prevalence with determined protozoan parasites

Table 2. in cyprinid aquaculture facilities in Macedonia

\begin{tabular}{|c|l|c|c|}
\hline \multicolumn{2}{|c|}{ Parasite species } & Mean intensity & Prevalence (\%) \\
\hline 1 & Apiosoma piscicola & 4.241 & 6.996 \\
\hline 2 & Chilodonella hexasticha & 1.800 & 0.441 \\
\hline 3 & Myxobolus müelleri & 3.400 & 0.441 \\
\hline 4 & Myxobolus encephalicus & 4.000 & 0.794 \\
\hline 5 & Thelohanellus nikolskii & 2.444 & 3.086 \\
\hline 6 & Ichthyophthirius multifiliis & 26.479 & 4.233 \\
\hline 7 & Trichodina sp. (Cyprinus carpio) & 4.567 & 30.159 \\
\hline 8 & Trichodina sp. (Ctenopharingodon idella) & 7.556 & 0.794 \\
\hline
\end{tabular}

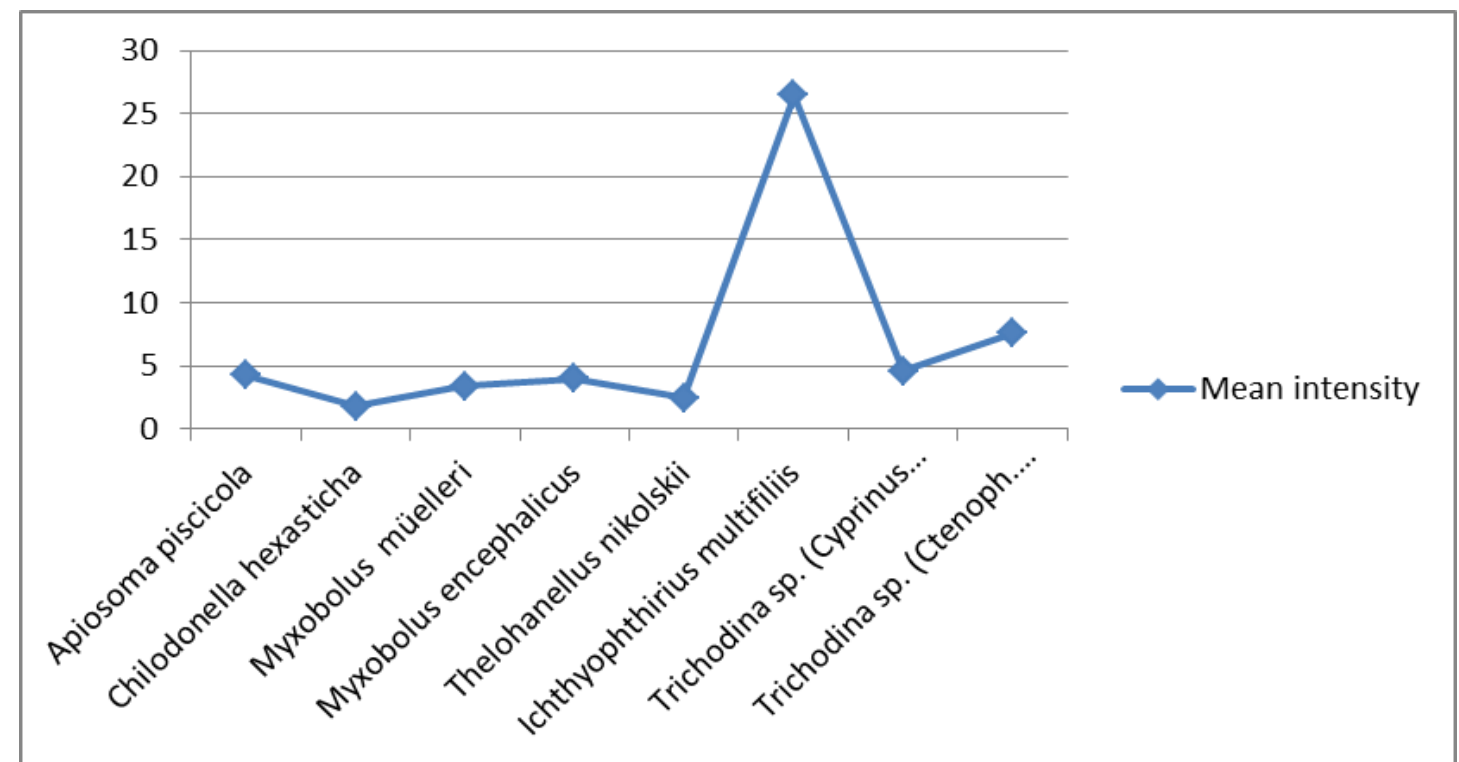

Fig. 1. Mean intensity with determined protozoan parasites in cyprinid aquaculture facilities in Macedonia

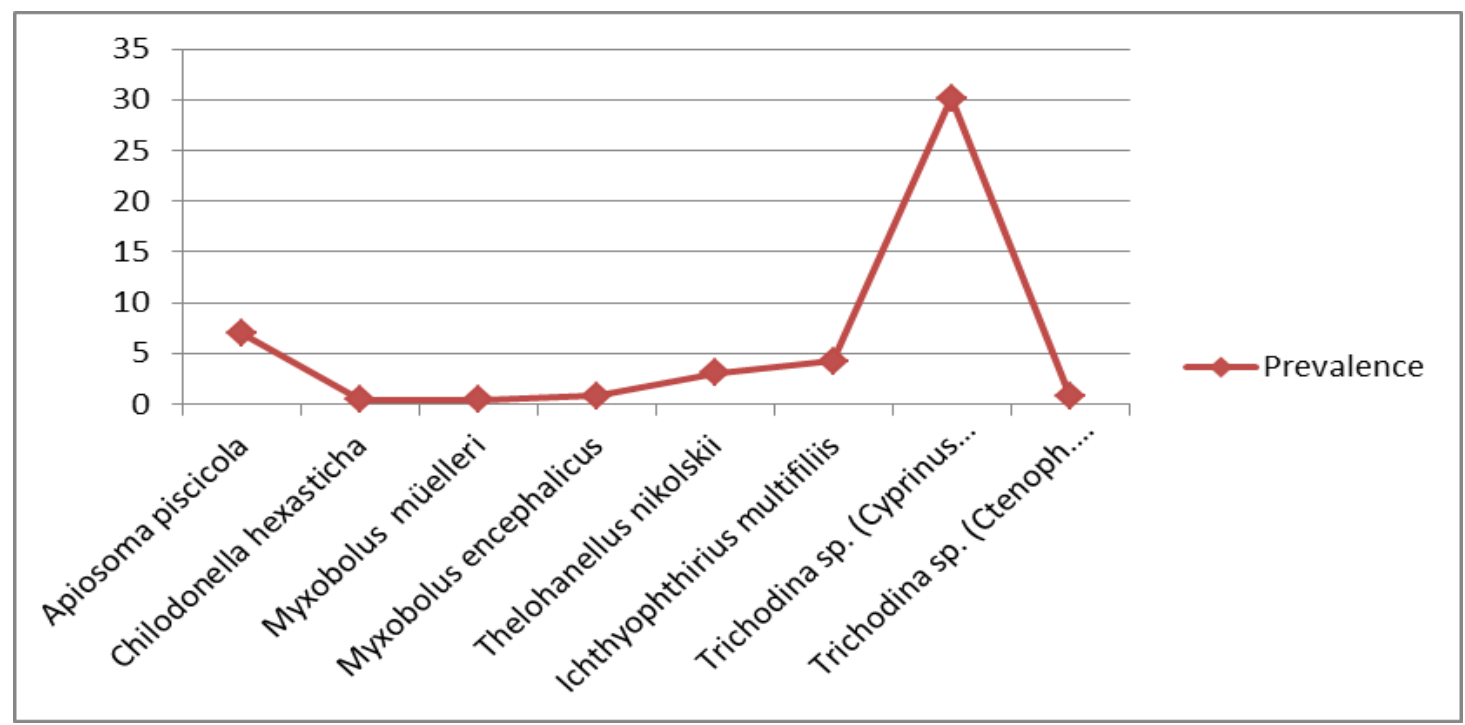

Fig. 2. Prevalence with determined protozoan parasites in cyprinid aquaculture facilities in Macedonia

Dijana BLAZHEKOVIKJ - DIMOVSKA, Stojmir STOJANOVSKI, Protozoan distribution in farmed cyprinid fish from Macedonia, Food and Environment Safety, Volume XX, Issue $1-2021$, pag. $35-42$ 
An infestation of protozoan parasites during the seasons

Table 3.

\begin{tabular}{|l|c|c|c|}
\hline Season & $\begin{array}{c}\text { Number of examined } \\
\text { fish }\end{array}$ & $\begin{array}{c}\text { Number of infected } \\
\text { fish }\end{array}$ & \% of infected fish \\
\hline Spring & 278 & 162 & 58.273 \\
\hline Summer & 279 & 109 & 39.068 \\
\hline Autumn & 289 & 103 & 35.640 \\
\hline Winter & 288 & 159 & 55.208 \\
\hline
\end{tabular}

Representatives of Protozoa most often occur during spring (in 58.273\% of examined fish), then in winter $(55.208 \%)$, summer $(39.068 \%)$, and less in autumn $(35.640 \%)$. Out of the total number of examined fish, 533 fish were infected with Protozoan parasites.

By seasons, the number of infected fish is spring - 162; summer - 109; autumn - 103 and winter - 159 fish (Table 3).

Table 4.

Prevalence (P) and mean intensity (I) with protozoan parasites in cyprinid aquaculture facilities in Macedonia, by seasons

\begin{tabular}{|l|c|c|c|c|c|c|c|c|}
\hline \multirow{2}{*}{\begin{tabular}{c}
\multirow{2}{*}{ Parasite species } \\
\multirow{2}{*}{ Spring }
\end{tabular}} & \multicolumn{2}{c|}{ Summer } & \multicolumn{2}{c|}{ Autumn } & \multicolumn{2}{c|}{ Winter } \\
\cline { 2 - 9 } & I & P(\%) & I & P(\%) & I & P(\%) & I & P(\%) \\
\hline Apiosoma piscicola & $/$ & $/$ & $/$ & $/$ & $/$ & $/$ & 4.241 & 6.966 \\
\hline Chilodonella hexasticha & 1.800 & 0.441 & $/$ & $/$ & $/$ & $/$ & $/$ & $/$ \\
\hline Myxobolus müelleri & 3.400 & 0.441 & $/$ & $/$ & $/$ & $/$ & $/$ & $/$ \\
\hline Myxobolus encephalicus & 4.000 & 0.794 & $/$ & $/$ & $/$ & $/$ & $/$ & $/$ \\
\hline Thelohanellus nikolskii & $/$ & $/$ & 2.444 & 3.086 & $/$ & $/$ & $/$ & $/$ \\
\hline Ichthyophthirius multifiliis & 12.556 & 0.794 & 26.706 & 2.998 & 50.00 & 0.441 & $/$ & $/$ \\
\hline Trichodina sp. (Cyprinus carpio) & 4.552 & 11.816 & 4.667 & 3.439 & 4.404 & 7.848 & 4.725 & 7.055 \\
\hline Trichodina sp. (Ctenoph. idella) & $/$ & $/$ & $/$ & $/$ & 7.556 & 0.794 & $/$ & $/$ \\
\hline
\end{tabular}

During our research, we noticed that the dynamics of parasite occurrence in fish varies depending on the parasite species and the season.

During the three-year research:

- 5 protozoan parasites species were identified in the spring, as follows: Chilodonella hexasticha, Myxobolus müelleri, Myxobolus encephalicus, Ichthyophthirius multifiliis, and Trichodina sp. (in common carp);

- 3 protozoan parasites species were found in the summer: Thelohanellus nikolskii, Ichthyophthirius multifiliis, and Trichodina sp. (in common carp);

- 3 protozoan parasites species were found in the autumn: Ichthyophthirius multifiliis, Trichodina sp. (in common carp), and Trichodina sp. (in grass carp);

- 2 protozoan parasites species were found in the winter: Apiosoma piscicola and Trichodina sp. (in common carp).

The highest prevalence $(11.816 \%)$ is confirmed with Trichodina sp. (in common carp) in spring, while the lowest $(0.441 \%)$ with Chilodonella hexasticha and Myxobolus müelleri in spring, as well as, Ichthyophthirius multifiliis in autumn.

The highest mean intensity (50.000) is determined with Ichthyophthirius multifiliis in autumn, while the lowest (1.800) with Chilodonella hexasticha in spring (Table 4).

Dijana BLAZHEKOVIKJ - DIMOVSKA, Stojmir STOJANOVSKI, Protozoan distribution in farmed cyprinid fish from Macedonia, Food and Environment Safety, Volume XX, Issue $1-2021$, pag. $35-42$ 
Total prevalence and mean intensity with determined protozoan parasites

Table 5. in common carp (Cyprinus carpio)

\begin{tabular}{|c|l|c|c|c|}
\hline \multicolumn{2}{|c|}{ Parasite species } & Number of infected fish & Mean intensity & Prevalence (\%) \\
\hline 1 & Apiosoma piscicola & 79 & 4.241 & 8.246 \\
\hline 2 & Chilodonella hexasticha & 5 & 1.800 & 0.522 \\
\hline 3 & Myxobolus muelleri & 5 & 3.400 & 0.522 \\
\hline 4 & Myxobolus encephalicus & 9 & 4.000 & 0.939 \\
\hline 5 & Thelohanellus nikolskii & 35 & 2.440 & 3.653 \\
\hline 6 & Ichthyophthirius multifiliis & 34 & 26.706 & 3.549 \\
\hline 7 & Trichodina sp. & 342 & 4.567 & 35.699 \\
\hline
\end{tabular}

*The calculations are based on the total number of examined samples of common carp (Cyprinus carpio) (958)

Table 6.

Total prevalence and mean intensity with determined protozoan parasites in grass carp (Ctenopharyngodon idella)

\begin{tabular}{|c|l|c|c|c|}
\hline \multicolumn{2}{|c|}{ Parasite species } & $\begin{array}{c}\text { Number of infected } \\
\text { fish }\end{array}$ & Mean intensity & Prevalence (\%) \\
\hline 1 & Ichthyophthirius multifiliis & 14 & 25.929 & 18.421 \\
\hline 2 & Trichodina sp. & 9 & 7.556 & 11.842 \\
\hline
\end{tabular}

Table 7.

Total prevalence and mean intensity with determined protozoan parasites in bighead carp (Hypophtalmichthys nobilis)

\begin{tabular}{|c|l|c|c|c|}
\hline \multicolumn{2}{|c|}{ Parasite species } & $\begin{array}{c}\text { Number of infected } \\
\text { fish }\end{array}$ & Mean intensity & Prevalence (\%) \\
\hline 1 & Ichthyophthirius multifiliis & 5 & 50.00 & 9.434 \\
\hline
\end{tabular}

*The calculations are based on the total number of examined samples of bighead carp (Hypophtalmichthys nobilis) (53)

By fish species, the highest prevalence $(35.699 \%)$ in common carp is confirmed with Trichodina sp., while the lowest $(0.522 \%)$ with Chilodonella hexasticha and Myxobolus müelleri. The highest mean intensity (26.706) is determined with Ichthyophthirius multifiliis, while the lowest (1.800) with Chilodonella hexasticha (Table 5).

In grass carp, the highest prevalence (18.421\%) and mean intensity (25.929) are determined with Ichthyophthirius multifiliis (Table 6). Ichthyophthirius multifiliis is the only protozoa found in bighead carp with a prevalence of $9.434 \%$ and a mean intensity, 50.000 (Table 7).

In this paper, for the first time, we published the result for the first finding of
Chilodonella hexasticha in common carp in Macedonia. At the same time, common carp is a new host for the Chilodonella hexasticha in Macedonian waters. In our research, Chilodonella hexasticha was found on the gills of 5 specimens of common carp in a fish farm in Dolneni, in spring. The prevalence with Chilodonella hexasticha in common carp was is 0.522 $\%$, while the mean intensity is 1.800 (Table 5).

The body of Chilodonella hexasticha is typically oval or leaf-shaped, dorsoventrally compressed, and is characterized by the presence of a groove at the end of the front of the body.

It has a length of $38.4(28.5-48.3) \mu \mathrm{m}$ and a width of $31.7(24.2-39.2) \mu \mathrm{m}$. The 
cytoplasm is ventrally granulated. The cytostome occurs in front of the naked area (zone without cilia). It leads to visible cytopharynx. The cytopharynx is protruding and secured with 8 to 10 visible cuticular bands, forming a funnel-shaped tube with a curved inner end. The cytopharynx may be slightly extruded and may form and destroy epithelial cells. Two contractile vacuoles are present. The macronucleus is round, 15 (13.5 - 16.5) $\mu \mathrm{m}$ long, and 12.7 (11.2 - 14.2) $\mu \mathrm{m}$ wide. The micronucleus is located near the macronucleus and has a length of 4.3 (3.5 5.1) $\mu \mathrm{m}$ and a width of $3.5(2.5-4.4) \mu \mathrm{m}$. According to literary reviews from the neighboring countries, the presence of Chilodonella hexasticha was established in waters in Serbia by [9].

According to the world's literary reviews, data on the appearance of representatives of the genus Chilodonella in common carp in fishponds in Iraq were published by [10], [11] and [12]. [13] found huge mortality in juveniles and adult carp in fishponds in Sri Lanka as a result of the presence of this protozoan.

The protozoan Chilodonella hexasticha is the causative agent of the parasitic disease chilodonellosis that attacks the skin, fins, and gills of common carp fry and fingerling up to 1 year of age. Adult fish appear as carriers of the parasite.

In [14] it stated that these cilia are morphologically well adapted to adhesion to the body surface and gills of fish and have a rapidly projected cytostomal opening. Therefore, they are obligate parasites in fish, causing direct damage by disrupting epithelial cells. [15] reported that infestations with Chilodonella hexasticha have been identified in both warm-water and cold-water fish worldwide, causing high mortality. In severe infestations with this parasite, the fish are weakened and dark discoloration is observed on the skin. [16] considered that as a result of the parasitism of Chilodonella hexasticha, severe damage to the gills occurs in the form of epithelial hyperplasia, which disrupts the fine respiratory epithelium, leading to fish mortality.

One of the symptoms of this disease is the swimming of fish on the surface of the water due to a lack of oxygen. Gray-blue deposits consisting of mucus and necrotic epithelial cells appear on the skin, fins, and gills. As a result, the fish itches from objects in the water, without taking food. Mortality depends on the fish size and the infestation degree.

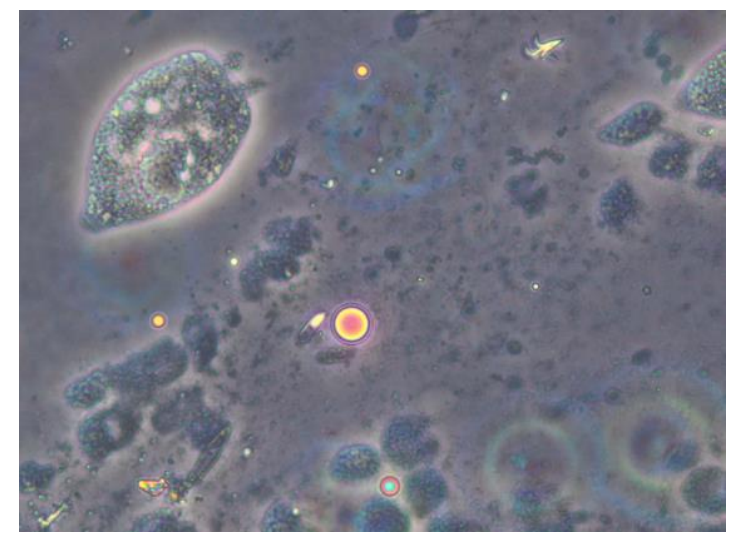

Fig.3 Apiosoma piscicola in common carp (Cyprinus carpio) (original)

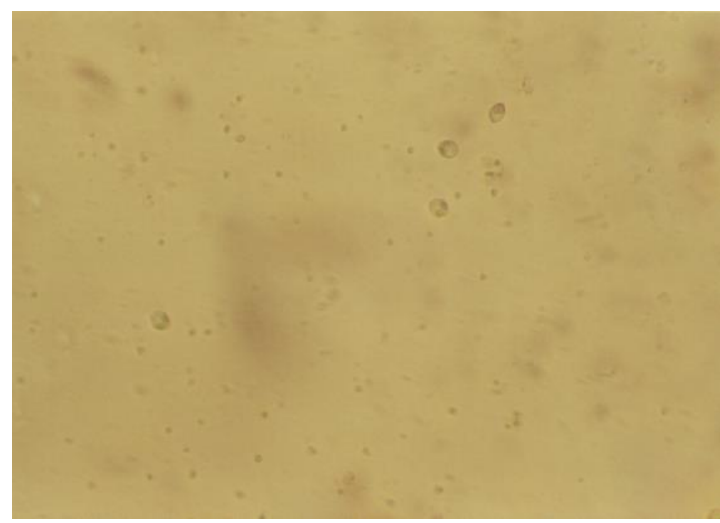

Fig. 4. Myxobolus encephalicus in common carp (Cyprinus carpio) (original) 


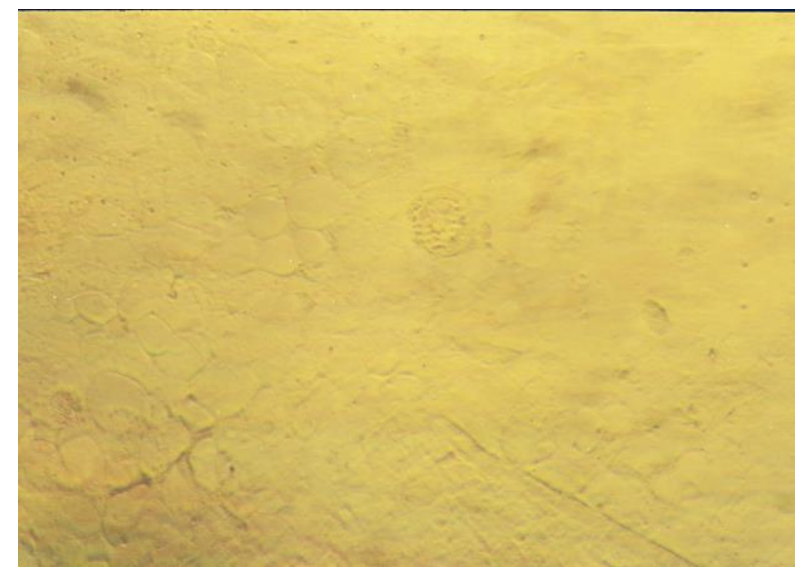

Fig.5. Trichodina sp. in grass carp (Ctenopharyngodon idella) (original)

\section{Conclusion}

Eight representatives of protozoan parasites in farmed cyprinid fish were identified in this study: Apiosoma piscicola, Chilodonella hexasticha, Myxobolus müelleri, Myxobolus encephalicus, Thelohanellus nikolskii, Ichthyophthirius multifiliis, Trichodina sp. (in common carp), and Trichodina sp. (in grass carp).

In cyprinid aquaculture facilities, based on the total fish examined, the highest prevalence with protozoan parasites is confirmed with Trichodina sp. (in common carp) while the lowest with Chilodonella hexasticha $(0.441 \%)$ and Myxobolus müelleri $(0.441 \%)$.

The highest mean intensity is determined with Ichthyophthirius multifiliis (26.479), while the lowest with Chilodonella hexasticha (1.800).

The finding of Chilodonella hexasticha in common carp (Cyprinus carpio) as a first record for Macedonian waters, is first published in this paper.

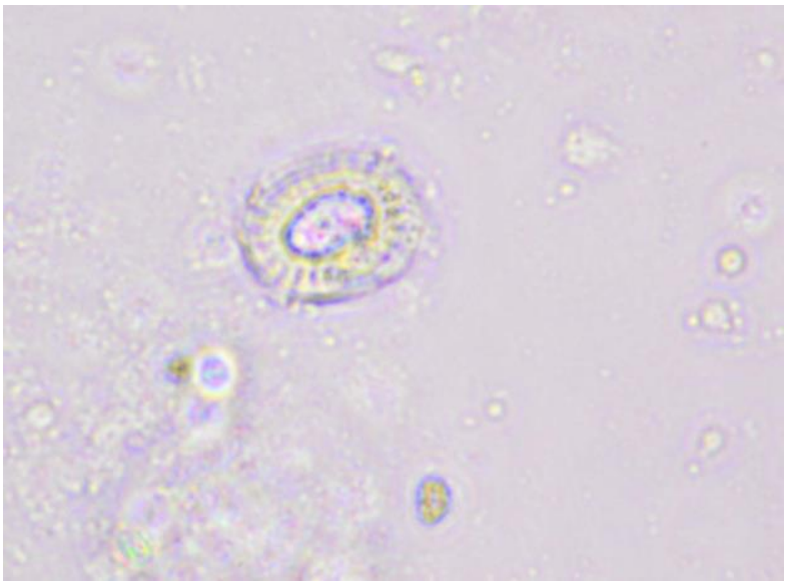

Fig.6. Trichodina sp. in common carp (Cyprinus carpio) (original)

In our research, infestation with Chilodonella hexasticha was determined in fish with reduced general resistance (unfavorable hygienic conditions, overpopulation, poor nutrition, skin injuries) in early spring, which correlates with literature data that the optimum temperature for Chilodonella development is about $10^{\circ} \mathrm{C}$. During the warm, summer months this parasite does not occur. It is most often observed in young carp in winterings or in spring when the fish are kept in these facilities for too long time. During this period, the fish are weakened and the low water temperatures are favorable for the development and multiplication of the parasite.

Representatives of the Protozoa were identified in all seasons, but the highest infestation was observed during spring and winter. During our research, we found that protozoa represent a huge problem in cyprinid aquaculture facilities, where high temperatures and organic matter content accelerate the life cycle of parasites and support their spread. 


\section{References}

[1] BONDAD-REANTASO G. M., SUBASINGHE R. P., ARTHUR R. J., OGAWA K., CHINABUT S., ADLARD R., TAN Z., SHARIFF M. (2005): Disease and health management in Asian aquaculture, Veterinary parasitology, 132, pp. 249 $-272$.

[2] STERUD E., SIMOLIN P., KVELLESTAD A. (2003): Infection by Parvicapsula sp. (Myxozoa) is associated with mortality in sea caged Atlantic salmon Salmo salar in northern Norway. Diseases of Aquatic Organisms, 54(3): 259-63.

[3] ENAYAT S.R. MOHAMED M. EL-NAGGAR, NAGWA M. ALI (2008): "Trichodinid ectoparasites (Ciliophora: Peritrichida) infecting the Nile cichlid fishes Sarotherodon galilaeus and Tilapia zillii at Dakahlia province, Egypt”. Egypt J. Zool., 51: 199 -219.

[4] HRISTOVSKI M., STOJANOVSKI S. (2005): Biologija, odgleduvanje i bolesti na ribite, Nacionalen forum za zastita na zivotnite na Makedonija, Skopje.

[5] WOO P.T. (2006): Fish diseases and disorders, Vol. 1: protozoan and metazoan infections. CAB International, London: pp.791.

[6] EL-TANTAWY S.A.M, EL-SHERBINY H.A.E. (2010): Some Protozoan Parasites Infecting Catfish Clarias gariepinus Inhabiting Nile Delta Water of the River Nile, Dakahlia Province, Egypt, Journal of American Science; 6 (9).

[7] BUSH A.O., LAFFERTY K.D., LOTZ J.M. and SHOSTAK A.W. (1997): Parasitology meets ecology on its own terms: Margolis et al. Revisited. J. Parasitology., 83: 575- 583.

[8] LOM J., DYKOVA I. (1992): Protozoan parasites of fishes. Elsevier, Amsterdam and London. pp. 315.

[9] CAKIĆ P. (1992): Paraziti riba u vodama Sjeniţko-Pešterske visoravni i mogucnosti njihovog suzbijanja. Doktorska disertacija. Veterinarski fakultet Univerziteta u Beogradu. Katedra za parazitologiju.
[10] ALI N. M., SALIH N. E., ABDUL-AMEER K. N. (1988): Protozoa and crustacea infesting three species of carp raised in ponds in Iraq, Journal of Biological Science Research, Vol. 19 No. 2, pp. 387-394.

[11] AL-MARJAN S.N. KARWAN, ABDULLAH M.A. SHAMALL (2008): Some ectoparasites of the common carp (Cyprinus carpio) in Ainkawa fish hatchery, Erbil Province, the 2nd Kurdistan Conference on Biological Sciences J. Duhok Univ. Vol.12, No.1 (Special Issue), pp. 102-107.

[12] MANSOOR N.T., AL-SHAIKH S.M.J. (2010): Protozoans infection of Cyprinus carpio L. from Bab Al-Muatham fish markets, Baghdad City, Iraqi Journal of Veterinary Medicine Vol. 34, No. 1.

[13] SUBASINGHE R. P. (1992): Hatchery diseases of freshwater fish in Sri Lanka. In, Diseases in Asian Aquaculture 1, edited by $\mathrm{M}$. Shariff, R. P. Subasinghe and J. R. Arthur, Asian Fisheries Society, Philippines.

[14] REDA E. S. A. (2011): A Review of some Ecto-and Endo Protozoan Parasites Infecting Sarotherodon galilaeus and Tilapia zillii from Damietta Branch of River Nile, Egypt, Journal of American Science; 7 (3).

[15] VAN AS J. G., BASSON L. (1988): The incidence and control of fish ectoparasitic protozoa in South Africa. Technical Communication, No. 211 Republic of South Africa.

[16] PAPERNA I., VAN AS J.G. (1983): The pathology of Chilodonella hexasticha (Kiernik). Infection in cichlid fishes. J. Fish. Biol. 23: 441450.

Dijana BLAZHEKOVIKJ - DIMOVSKA, Stojmir STOJANOVSKI, Protozoan distribution in farmed cyprinid fish from Macedonia, Food and Environment Safety, Volume XX, Issue 1 -2021, pag. $35-42$ 